\title{
СУГЛАСНИЧКЕ АЛТЕРНАЦИЈЕ У ДЕКЛИНАЦИЈИ И КОНЈУГАЦИЈИ У СРПСКОМ И РУСКОМ ЈЕЗИКУ (ДИЈАХРОНИЈСКИ И СИНХРОНИЈСКИ АСПЕКТ)
}

\begin{abstract}
У овом раду се испитује судбина сугласничких алтернација у именичким деклинацијама и у презенту и императиву глагола, које су се у староруском језику добро чувале као и у старословенском језику, а потом се ово стање пореди са стањем у савременим језицима, руском и српском. Српски језик је у овом погледу архаичнији: он боље чува резултате и прве и друге палатализације задњонепчаних сугласника, и у именичким деклинацијама, и у императиву, и у презенту, док се у руском језику чувају сугласничке алтернације у садашњем (и простом будућем) времену засноване на резултатима прве палатализације. У руском језику је био шири утицај аналогије (изједначавање основа), док је у српском језику аналогија била више обличка него фонетска (губљење старих облика локатива једнине и локатива множине данашње прве деклинације).

Кључне речи: задњонепчани сугласници, палатализација, алтернација, деклинација, конјугација
\end{abstract}

\section{Увод}

0.1. Сугласничке алтернације (руски: чередования согласных) у деклинацији и конјугацији у раном староруском језику тичу се резултата прве и друге палатализације задњонепчаних сугласника. У руској научној мисли чешће се употребљава израз „умекшавање задњонепчаних сугласника”, неки аутори чак термин палатализација користе под наводницима (Чекман 1979), али то је више питање научне традиције него неке принципијелне разлике. Beћ додавање термину атрибутске синтагме (смягчение) задненебных со- 
гласных има принципијелни значај јер су се палатализовали и остали тврди сугласници испред вокала предњег реда, а то је за историјску русистику важно (ти полумеки сугласници су касније потпуно умекшани прешавши у палаталне фонеме).

У српској лингвистичкој школи, почев од Александра Белића, говори се о три палатализације (Вуковић 1974: 143-159), а у дијахроној русистици често се полази од две палатализације (друга и трећа се посматрају као једна). За овај рад та терминолошка разлика није битна пошто трећа палатализација неће ни бити предмет посебног разматрања с обзиром на то да се њени резултати рефлектују, пре свега, у деривацији.

У зависности од коначног резултата умекшавања, задњонепчани $\kappa, 2, x$ у прасловенском испред вокала предњег реда првом палатализацијом промењени су у шушкаве ч', ж’, $u^{\prime}$. Друга палатализација се такође десила током прасловенске епохе, али након прве, тачније након монофтонгизације дифтонга, до које је дошло у многим језицима, али у различито време и у различитом степену (Савченко 1974: 88), када су задњонепчани промењени у пискаве $u^{\prime}$, з', $^{\prime}$ '. Ова промена се догодила, прво, у случају када су се $\kappa, 2$, $x$ налазили у положају испред вокала [i] и [е̌], који воде порекло од дифтонга [oi], [ai]. Иста промена у пискаве је била и у позицији после вокала предњег реда [i], [ь], [е], али неконсеквентно, са мноштвом одступања (Иванов 1983: 126). Даље Иванов говори да „вопрос о том, какая из разновидностей второй палатализации осуществлялась раньше, а какая - позже, не является решенным: одни лингвисты полагают, что раньше осуществлялось изменение $\kappa, 2, x$ перед [i] и [е̌] из дифтонгов, другие наоборот, - что раньше шло изменение $\kappa, 2, x$ после гласных переднего ряда. Проще и яснее обстоит дело с установлением относительной хронологии в отношении первой и второй палатализации: здесь есть вполне реальные доказательства, что изменение $\kappa, 2, x$ в шипящие осуществлялось раньше, чем в свистящие (Иванов 1983: 127). Питањима хронологије друге палатализације је посвећено доста пажње у радовима слависта, сматра се да се десила не касније од V до X в. н.е. (Чекман 1979: 100).

Староруски језик се у погледу резултата друге палатализације не разликује од старословенског, осим једне појединости која је само хронолошка: у старословенском смо још имали опозицију $g: d z$ ', у староруском језику африката $d z$ ' већ је била упрошћена, па смо имали однос $g: z$ '.

0.2. Предмет нашег рада су алтернације у првој и другој именичкој деклинацији (старе основе на *о̌ и старе основе на $* \bar{a})$, у императиву и у презенту. Изван наше анализе остаје однос презента могу и инфинитива (српски) моћи, (староруски) мочи. А зашто га изостављамо? С једне стране, зато што инфинитив није облик конјугације, а с друге стране, зато што је инфинитивно $\hbar / \iota$ резултат јотовања $m$, док задњонепчани сугласник из презента алтернира са одсуством гласа у инфинитиву (задњонепчано $\kappa, 2, x$ испред сугласника $m$, пошто је условило његово јотовање, само се изгубило).

0.3. Изван наше анализе остављамо и алтернације у имперфекту. У староруском језику су се имперфекат и аорист изгубили, а старе алтернације 
$c: x$ и $x: u$ нису више карактерисале границе морфема него су ушле у састав флексије. Однос пак сеђаше : седијаше предмет је историје српског језика, а у староруским облицима типа хотюшє изостаје јотовање па секвенце типа тв треба посматрати као [tija] или [tbja].

\section{Основа поређења}

1. За сваку поредбену анализу, било да је та анализа дијахрона или синхрона, или и једна и друга, потребно је одредити основу поређења, тј. оно што се у методологији зове tertium comparationis. Испитујући типолошко диференцирање руског и српског језика, Р. Маројевић истиче следеће: „Введение в лингвистическое исследование понятия типологического расхождения предполагает выявление типологических особенностей современного русского и современного сербского языков в сопоставлении с праславянским, играющим роль 'tertium comparationis"' (Маројевић 2015: 8).

2. И за тему овог рада таква методологија се подразумева. Проблем је, међутим, у томе што се почетне фазе у развоју двају језика на консонантском плану не подударају у свему и што су тенденције у развоју од самог почетка биле различите.

У старосрпском и староруском као прасловенским дијалектима специфично је било јотовање сугласника $t$ и $d$. У српском гласовне групе *tj и * dj дале су нове, специфичне српске гласове, $\hbar$ и $\hbar$, а у руском сугласнике добијене првом палатализацијом, ч и ж. Разлика се проширила и на две рецензије црквенословенског језика, у српској је $m$ алтернирало са $\varkappa m$, а у руској са щ, (у обе рецензије $\partial$ алтернира са жd). Полумеки сугласници су у српском имали тенденцију да ту полумекоћу изгубе и изједначе се и фонетски с тврдим сугласницима, а у руском да се потпуно умекшају, што се у оба језика као процес и завршило.

Руски језик је од почетка имао тенденцију губљења резултата друге палатализације задњонепчаних сугласника као резултат изједначавања основа (руски: выравнивание основ). Испитујући развитак суфикса у јужнословенским језицима, Р. Бошковић је показао да у њима носе превагу суфикси с елементом $u$, а у источним и западним словенским језицима - суфикси с елементом $\kappa$ (Бошковић 1978: 49-175). У руском језику се тако аналошки вратио сугласник $\kappa$ који је у неким облицима био замењен са $u$, па су у руском веома продуктивни суфикси -ик, -ико, -ика, -ка и др. Да то не важи само за суфиксе и за задњонепчани сугласник $к$, показује следећи пример. У Речнику црквенословенског и руског језика Другог одељења Императорске академије наука, у чијој изради је активно суделовао А. Востоков, наводе се и глагол дви́гАТься, с променом -аюсь, -аешься и дви́жусь, дви́жешься, и глагол двизА́тися, са ознаком Церк. и променом -за́юся, -за́ешися (Востоков и др. 1847/2001 I: 309). У руском глаголу је васпостављен сугласник г у корену |двиг|, чиме је изостала алтернација по трећој палатализацији (2 : 3), коју руски 
аутори укључују у другу палатализацију, али је у конјугацији остао ефекат прве палатализације (и алтернација г : ж).

\section{Деклинација}

3. У првој деклинацији имали смо, у староруском (и старословенском, односно у прасловенском), и алтернацију засновану на првој палатализацији (у вокативу једнине: вълкъ - вълче), и алтернацију засновану на другој палатализацији (у локативу једнине вълиъ, номинативу множине въличи, и локативу множине вълцъхъ).

Ефекат прве палатализације у српском језику се чува, а и у руском језику би се сачувао (о чему сведочи реликт Боже) да није упрошћен падешки систем - изгубио се вокатив.

Како наводе аутори историјске граматике руског језика, трагови друге палатализације у морфолошој структури савременог руског језика су скоро нестали, могу се срести у неким фразеологизмима старословенског порекла: притча во языцех, в бозе почил, вода во облацех и др. (БСУ 1974: 74).

С обзиром на то да при другој палатализацији задњонепчани бивају замењени сибилантима $u$, з и $c$, промена се још назива и сибиларизацијом.

Ефекат друге палатализације, односно алтернација на њој заснована, чува се у српском: у номинативу множине и дативу, инструменталу, локативу множине именица мушког рода чија се основа завршава на задњонепчани сугласник: јунак : јунащи, јунащима; улог: улози, улозима; дух : дуси, дусима, вук : вуции, вуц̧има. Са локатива множине проширио се ефекат друге палатализације на датив и инструментал у вези са синкретизмом ова три множинска падежа (вуцима). Промена се најдоследније врши у множинским падежима именица мушког рода: ђаци, Ђаџима; јунаци, јунацима; задаци, задацимма. Ефекат друге палатализације у локативу једнине старих основа на *о̌ није се сачувао, али из морфолошких а не из фонетских разлога: дошло је до синкретизма локатива са дативом, а утицале су и старе основе на *ŭ са својим наставком у локативу.

У руском језику ефекти друге палатализације су се изгубили у локативу једнине и номинативу множине: (о) волке < волиъ, волки < вълции, док се у локативу множине пренео наставак -ах старих *ā основа: (о) волках.

Према речима В.И. Собињикове, губљење алтернације $\kappa, 2, x$ са $u, 3, c$ почело је од раних новгородских споменика, одакле се, из северноруских говора, проширило на целу територију руског језика (Собињикова 1967: 31). Овај процес није могуће сагледати по етапама и правцима, без обзира на то што је наука о историји руског језика, чији извори воде ка Ломоносову, средином XX века сакупила богат фактички материјал о појавама и процесима у развоју фонетике, морфологије и синтаксе руског језика те разрадила методе реконструкције прошлог стања језичког система на основу споменика писмености и савремених дијалеката (ИРЈЛИ 1987: 3). Б. Ларин је чак говорио да, 
ако би картографски била приказана лингвистичка обрада савремене Европе, најупечатљивија празнина не би била на удаљеним и неприступачним местима, већ управо у великим градовима (Ларин 1928: 61). С. Котков у истраживању московског говора на почетку формирања руског националног језика, наведену ситуацију објашњава великим приливом становништва из различитих делова Русије, јер политичка и економска доминација Москве, њен централизован утицај већ од XIV века, бива условљена доласком носилаца како северновеликоруких, тако и јужновеликоруких говора (Котков 1974: 18).

4. У другој деклинацији ефекат друге палатализације имали смо у номинативу-акузативу-вокативу двојине и у дативу-локативу једнине (роуц̧ъ). Овде је, према В. Иванову, „очень рано начала действовать тенденция выравнивания основ, в результате чего свистящие перед окончанием е̌ стали вытеснятся заднеязычными [к], [г], [х]. Так возникли формы роукъ-руке" (Иванов 1983: 292).

У српском језику алтернација се чува, наравно, само у једнини (двојина се изгубила). Ефекат имамо у дативу и локативу једнине именица женског рода, чија се основа завршава на задњонепчани сугласник - рука : руци; нога: нози, епоха : епоси (али и епохи), али су стари облици замењени аналошким: нозъ $\rightarrow$ нози, роуцъ $\rightarrow$ руц̧и. То је унификација тврде и меке деклинације, у српском језику у корист меке, а у руском у корист тврде.

Алтернација није обавезна у свим речима. Александар Белић наводи многобројна одступања у целим категоријама у којима се и у књижевном језику не врши ова промена (Белић 2006: 106). Јован Вуковић додаје да, на пример, аналошко $\kappa$ уместо ч из прве палатализације у књижевном језику имамо код властитих имена и придева од именица хипокористичног карактеpa: Анка - Анкин, сека - секин; у којима је подударност разумљива, јер у породичном животу хипокористичне именице обично функционишу као лична имена (Вуковић 1974: 146).

У дативу и локативу једнине именица на - $а$ одступања су честа. Актуелни правопис (према издању из 2010. године) препоручује као правилне об-

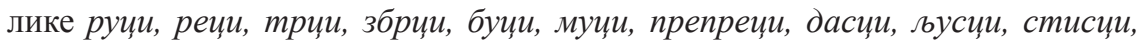
дршщи, љуљашции, нози, слози, књизи, бризи, нези, сврси, али и: свастици, хуции, вашщи, кокошщи, крушщии, пушци, четворичи, влази, тузи. У неким од ових других примера све обичније постаје изједначавање основе, тј. замена $u$, з, с са $\kappa$, , $x$ : вашки, пушки, кокошки, мада то норма још није изричито прихватила. Дублети су у савременом српском дозвољени у примерима као: ћерки и ћерци, слуги и слузи, снахи и (ређе) снаси, епохи и епоси, маски и масии, фресиии и фрески, хуморесции и хуморески (Правопис 2010).

У руском језику ефекти друге палатализације су се изгубили, али се појавила алтернација по тврдоћи-мекоћи, у којој се меки сугласник проширио и на облике генитива једнине, номинатива-акузатива множине после промене $\kappa b l, z b l, x b l \rightarrow \kappa u, z u, x u$ (роукbl-руки). В. Иванов сматра да се почетак овог процеса односи на XII/XIII век (Иванов 1983: 211), тачније: крајем XII и почетком XIII века. С обзиром на то да се и фонолошка разлика између меког и полумеког сугласника чувала све до краја XII и првих деценија XIII 
века (Маројевић 2015б: 146), може се сматрати да су се два процеса дешавала (промена $\kappa b l, z b l, x b l \rightarrow \kappa u, z u, x u$ и умекшавање полумеких сугласника) истовремено. Ф. Филин прецизира да су у ХІІ и првом половином XIII в.

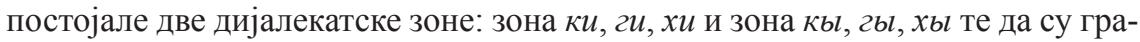
нице међу њима од најранијег периода биле мобилне. Након ширења умекшавања задњонепчаних скоро на целу источнословенску територију, губи се супротстављање умекшаних и неумекшаних $\kappa, 2, x$. Ретки примери изговора $\kappa b l, z b l, x b l$ постају дијалекатске особине (Филин 1972: 307).

\section{Конјугација}

5. У императиву у српском језику се сачувала сугласничка алтернација заснована на ефекту друге палатализације: помози. Промене које су се десиле биле су условљене аналогијом и тицале су се морфемике, а не ове алтернације: помозъте $\rightarrow$ помозите, пьции $\rightarrow$ пец̧и. Ови облици аналогије карактеришу и историју руског језика. Код Иванова налазимо примере пекоу - пьичи, текоу - тьиъте, берегоу - березъмъ, али су се у руском изгубили ефекти друге палатализације и у императиву, па у савременом језику имамо: помоги/помогите, береги/берегите, пеки/пеките, али: ляг/лягте. У оба језика су се иначе изгубили синтетички облици 3. лица једнине императива, као и императиви двојине. Облици 1. лица множине императива у српском су се сачували (помозимо), док су се у руском изгубили (дошло је до мешања са презентом, па данас облици садашњег и простог будућег времена, без употребљене личне заменице, могу имати значење императива).

6. Конјугација облика садашњег времена у староруском језику је са аспекта индоевропских корелација била архаичнија него старословенска (ГХ 1997: 307). У презенту је дата алтернација, заснована на ефекту прве палатализације, сачувана и у руском: (я) могу, (они) могут - (он) может; (я) пеку, (они) пекут - (он) печёт, и у српском језику: (ја) могу, (они) могу - (он) може; (они) пеку - (он) пече, (ја) печем.

У руском језику, међутим, као и у деклинацији, поред алтернације засноване на резултату прве палатализације развила се алтернација заснована на умекшавању полумеких сугласника (у првој конјугацији), која се фонологизовала: (я) несу, (они) несут - (он) несёт.

\section{Закључак}

7.1. Српски језик и цео ,јужнословенски ареал је сачувао архаичнији сугласнички систем" (Фурдал 1959: 181) и ближи је не само старословенском него и староруском. Он чува алтернације засноване на првој и другој палатализацији задњонепчаних сугласника, само што се делимично изменила дис- 
трибуција алтернаната, с тим што узрок тим изменама није фонетски него морфолошки.

7.2. У руском језику су се чували резултати прве палатализације, али су се они и сачували само у конјугацији, док се у деклинацији чува само као реликт старог стања некадашњи вокатив Боже. Узрок губљења ове алтернације у деклинацији није фонетски већ морфолошки (функцију вокатива преузео је номинатив).

У руском језику су се изгубили резултати друге палатализације и у деклинацији и у конјугацији као резултат процеса изједначавања основа.

7.3. Како истиче Р. Маројевић, типолошке разлике између руског и српског језика на фонолошком нивоу појавиле су се, пре свега, услед промена у консонантском и вокалском нивоу. На консонантском нивоу то је следећа промена: „В результате смягчения полумягких согласных в русском языке сформировалась оппозиция по твердости - мягкости согласных как релевантный фонологический признак” (Маројевић 2015a: 10). Као резултат умекшавања полумеких сугласника у староруском језику појавила се нова, специфична руска алтернација тврдих и меких сугласника која је обухватила облике и деклинације и конјугације.

Треба истаћи да се алтернација по тврдоћи - мекоћи у руском језику не појављује у свим облицима деклинације и конјугације. У трећој деклинацији у именицама типа радость имамо ефекат секундарне мекоће у свим падежима, што значи да нема алтернације $m / m$ '. Исто тако у другој конјугацији ефекат секундарног умекшавања сугласника карактерише и 1. лице једнине и 3. лице множине, тј. сва лица: говорю, говоришь, говорят.

\section{ЛИТЕРАТУРА}

Белић 2006: Александар Белић, Историја српског језика, Београд: Завод за уџбенике и наставна средства.

Бошковић 1978: Радосав Бошковић, Одабрани чланџи и расправе, Титоград: ЦАНУ.

БСУ 1974: Н. И. Букатевич, С. А. Савицкая, Усачева Л.Я., Историческая грамматика русского языка, Киев: Вища школа.

Востоков и др. 1847/2001: Словарь ичерковно-славянскаго и русскаго языка, составленный Вторымъ Отдъленіемъ Императорской Академіи Наукъ. Томъ I, Санктпетербургъ: Въ Типографіи Императорской Академіи Наукъ, [Репринтное издание:] Словарь изерковнославянского и русского языка, составленный вторым отделением Императорской Академии Наук. В 2-х кн. Кн. 1, Санкт-Петербург: Издательство Санкт-Петербургского университета.

Вуковић 1974: Jovan Vuković, Istorija srpskohrvatskog jezika. Uvod i fonetika, Beograd: Naučna knjiga.

ГХ 1997: К. В. Горшкова, Г. А. Хабургаев, Историческая грамматика русского языка, Москва: Издательство Московского университета. 
Иванов 1983: В. В. Иванов, Историческая грамматика русского языка, Москва: Просвещение.

ИРЈЛИ 1987: История русского языка и лингвистическое источниковедение, Ответственные редакторы В. В. Иванов и А. И. Сумникова, Москва: Наука.

Котков 1974: С. И. Котков, Московская речь в начальный период становления русского национального языка, Москва: Наука.

Ларин 1928: Б. А. Ларин, О лингвистическом изучении города, у: Русская речь, вып. ІІІ, Ленинград.

Маројевић 2015a: Радмило Мароевич, Русская грамматика: Сопоставительная грамматика русского и сербского языков с историческими комментариями. В двух томах. Том I. Типология. Фонология. Морфология имени, Бања Лука: Panevropski univerzitet Apeiron Banja Luka.

Маројевић 2015б: Радмило Маројевић, Посесивне изведенице у староруском језику: Антропонимски систем. Топонимија. „Слово о полку Игореве", Бања Лука: Panevropski univerzitet Apeiron Banja Luka.

Правопис 2010: Мато Пижурица, Митар Пешикан, Јован Јерковић, Правопис српскога језика, Нови Сад: Матица српска.

Савченко 1974: А.Н.Савченко, Сравнительная грамматика индоевропейских языков. Москва: Высшая школа.

Собињикова 1967: В. И. Собинникова, Лекции по исторической грамматике русского языка, Воронеж: Издательство Воронежского университета.

Филин 1972: Ф. П. Филин, Происхождение русского, белорусского и украинского языков, Ленинград: Наука.

Фурдал 1959: A. Furdal, Uwagi o rozwoju słowiańskiej kategorii palatalności, Wrocław: Rozprawy komisji językowej.

Чекман 1979: В. Н. Чекман, Исследования по исторической фонетике праславянского языка. Типология и реконструкция, Минск: Наука и техника.

\author{
Е. Байович
}

\begin{abstract}
ЧЕРЕДОВАНИЯ СОГЛАСНЫХ В СКЛОНЕНИИ И СПРЯЖЕНИИ В СЕРБСКОМ
И РУССКОМ ЯЗЫКАХ (СИНХРОННЫЙ И ДИАХРОННЫЙ АСПЕКТЫ)
\end{abstract}

\title{
Ре зюме
}

В настоящей статье рассматриваются чередования согласных в именных склонениях, а также в формах настоящего времени и повелительного наклонения, которые в древнерусском как и в старославянском сохранялись, в сопоставлении со современными языками - русским и сербским. Сербский язык в этом аспекте архаичнее: в нем сохраняются результаты первого и второго смягчения задненебных согласных, и в именном склонении, и в императиве, и в презенте, в то время как в русском языке сохраняются чередования согласных в настоящем (и простом будущем) времени, основанные на результатах первого смягчения задненебных согласных. В русском языке наблюдается более широкое влияние аналогии (выравнивания основ), в то время как в сербском языке аналогия была в большей степени морфологическим, чем фонетическим 
явлением (утрата прежних форм единственного и множественного чисел местного падежа первого склонения в современном сербском языке).

Ключевые слова: задненебные согласные, чередования согласных, смягчение задненебных согласных, склонение, спряжение. 